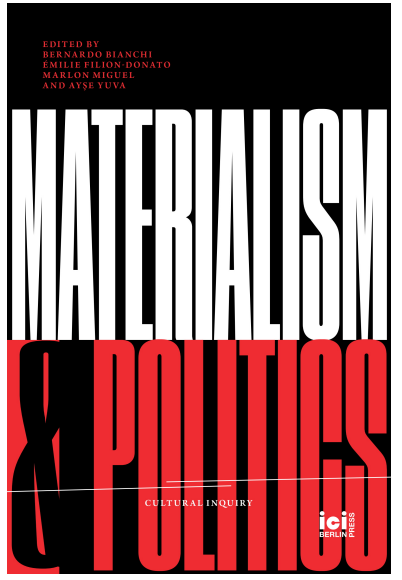

Materialism and Politics, ed. by Bernardo $\mathrm{Bi}$ anchi, Emilie Filion-Donato, Marlon Miguel, and Ayşe Yuva, Cultural Inquiry, 20 (Berlin: ICI Berlin Press, 2021), pp. 181-96
PASCAL SÉVÉRAC

\section{A Materialist Education}

Thinking with Spinoza

CITE AS:

Pascal Sévérac, 'A Materialist Education: Thinking with Spinoza', in Materialism and Politics, ed. by Bernardo Bianchi, Emilie FilionDonato, Marlon Miguel, and Ayşe Yuva, Cultural Inquiry, 20 (Berlin: ICI Berlin Press, 2021), pp. 181-96<https://doi.org/10. 37050/ci-20_10>

RIGHTS STATEMENT:

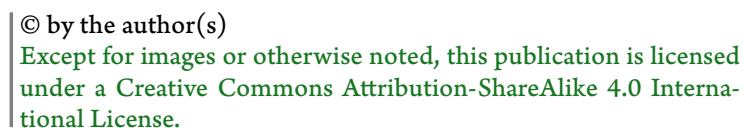
under a Creative Commons Attribution-ShareAlike 4.0 International License.

ABSTRACT: Spinoza never wrote the 'science of education' he refers to in the Treatise on the Emendation of the Intellect. But I will argue that an ethical education can be deduced from his philosophy, which proposes a materialist education in the sense that it aims at a transformation of the affective sensibility of the body. Such an education should be understood as a re-education or counter-education, instead of what we ordinarily understand as education, which is a moral education.

KEYWORDS: education - children; body and mind; affective sensibility; transformation; affect (psychology); child development; moral education; ethical education 


\section{A Materialist Education}

\section{Thinking with Spinoza}

PASCAL SÉVÉRAC

\section{THREE MEANINGS OF MATERIALISM}

I would like to lay the foundations for what can be called, from Spinoza onwards, a 'materialist education'. Let me clarify from the outset three different meanings of 'materialism' which we can use to understand a 'materialist education':

First, in the empirical or immediate sense, that is, in the sense that a person, a behaviour, or an ideology is said to be materialistic when what is valued is material goods. Therefore, 'to be materialistic' is less a label that is claimed than a label that is applied, often to depreciate what is deemed to be materialistic. This definition of 'materialistic' implies a way of living and thinking that values money, carnal pleasures, and material comfort - in short, a way of life that is probably considered too selfish or individualistic, and that would seem to detract from higher values such as generosity or solidarity, or spiritual values that are more concerned with the salvation of souls than with the enjoyment of bodies. I do not wish to discard this meaning of 'materialism', because being materialistic has something to do with being a materialist, i.e.

\footnotetext{
* Author affiliation: Univ Paris Est Creteil, LIS, F-94010 Creteil, France
} 
a follower of materialism (especially since in some languages, such as French, there is only one word: 'matérialiste').

Secondly, 'materialism' can be understood ontologically, that is, in the sense of a reduction of reality to matter alone: this 'materialist' conception of the world considers consciousness as a function of the body, the mind as an emanation of the brain, and thought as a production of matter. As Félix Ravaisson said, when attributing this definition to Auguste Comte, materialism is the 'doctrine that explains the superior by the inferior' ${ }^{1}$ of course, this is a definition proposed by a spiritualist who devalued materialist philosophies. But why should consciousness be superior to the body or mind superior to the brain? Such an idea presupposes a common measure between these two kinds of reality, a presumption that Spinozism had already begun to challenge.

Thirdly and finally, it is possible to identify a 'methodological' materialism that does not itself pronounce on the nature of reality by trying to answer questions such as whether there is a difference in nature between thought and matter or a possible reduction of thought to matter; instead, it studies psychic or mental phenomena in the same way as it would study material or bodily phenomena, that is to say, by taking them as the object of a causal, deterministic explanation, or, as we say today, by 'naturalizing' them. In fact, methodological materialism is based on the idea that the reality of thought or of the psyche (ideas, affects) obeys natural necessity in the same way that the reality of matter or of the organism (the movements of the body) does.

So, from what point of view should a materialist education be understood? I will immediately exclude the second meaning of ontological materialism: Spinoza does not conceive of thought as something reducible to matter. If we can derive a materialist education from his philosophy, it is not in the sense that it adopts such a position on the nature of reality, and therefore on the nature of the first object of education - the child. The child, just like any human being, has a mind, comprised of a psychological or cognitive system, which follows its own laws, and which cannot be reduced to bodily, physiological,

1 Félix Ravaisson, La Philosophie en France au $\mathrm{XIx}^{e}$ siècle (1867) (Paris: Vrin Reprise, 1983), p. 189: 'Selon l'excellente définition d'Auguste Comte [...], le matérialisme est la doctrine qui explique le supérieur par l'inférieur'. 
and especially cerebral or neural laws. Educating a child is therefore not just about impacting a brain.

Spinoza can be described as 'materialist' in the third sense that we have identified, that is, in the methodological sense: this is a nonreductionist materialism, which considers the mind a natural thing that can be studied as bodies are studied. At the end of the preface to the third part of Ethics, Spinoza explicitly declares that he intends to study psychic phenomena as if they were 'lines, planes, and bodies' ${ }^{2}$ he intends to geometrize the psyche in the same way that science geometrizes an organism, and to use this method to study the properties and causal laws of bodies, in particular of human bodies. The foundations of a physics of thought are laid on the same model as the physics of matter. However, it should be noted in passing that this methodological materialism is itself based on a certain ontological conception of reality: it is because both thought and matter are in fact the same reality conceived under a different kind of being that it is methodologically necessary to study psychic phenomena as we study material phenomena - or to study material phenomena as we should study psychic phenomena, that is, as phenomena of a single and unique Nature that is regulated by precisely determined laws. ${ }^{3}$

From the point of view of education, this non-reductionist, methodological materialism means two things:

First, that such education consists in impacting on both the psyche and the organism; education in this sense is a way of guiding human behaviour, a way of directing human conduct, the purpose of which is not to allow the child's 'free will' to be exercised. Indeed, from the point of view of a materialist, that is, deterministic education, such free will does not exist; on the contrary, belief in free will is an illusion which the moral system of judgment is based upon. In other words, a materialist education does not have as its ultimate purpose the conferral of self-responsibility, but rather self-knowledge; it is not meant to teach obedience to moral rules but knowledge of procedural

2 Ethics III, Praef.; CWS [The Collected Works of Spinoza, see abbreviations], I, p. 492.

3 See Ethics, III, Praef.: 'nature is always the same, and its virtue and power of acting are everywhere one and the same, that is, the laws and rules of nature, according to which all things happen, and change from one form to another, are always and everywhere the same. So the way of understanding the nature of anything, of whatever kind, must also be the same, namely, through the universal laws and rules of nature' (ibid.). 
rules (knowledge of the procedures that regulate behaviour, self, and other).

Secondly, another meaning of a non-reductionist, materialist education is that the mind is considered an automaton that is regulated in a determined way, just as the body is regulated as a physical automaton. This does not mean that consciousness does not matter: the mind may be a 'spiritual automaton' determined by laws, but it still feels what it is thinking. ${ }^{4}$ The child's materialist education is not a behavioural education, or rather, it is a behavioural education insofar as it involves an education of consciousness, which is experience as it is lived in the first person. The way a child experiences things does, of course, have an effect on his behaviour, and this is why an education of behaviour must be an education of the way things are lived, felt, and understood.

Nevertheless, the education that can be derived from Spinoza's thought is perhaps also a materialist education in the first sense that we have given to this term: namely, the empirical meaning of a very particular care given to the body and also, in a sense, to the enjoyment of its power. Let me explain. We have seen that Spinoza's materialism is not a reductionist materialism, which would lose interest in psychological interiority and focus only on external behaviour. Nevertheless, it must also be seen that, from a Spinozist point of view, the mind is the idea of a body existing in action: consciousness is consciousness of a living, affected, and affecting body. The mind is all the more powerful because it is the idea of a body that is itself more developed, more active: 'in proportion as a body is more capable than others of doing many things at once, or being acted on in many ways at once, so its mind is more capable than others of perceiving many at once', says the Scholium of proposition 12 of Ethics III.

It is the strength of the capacity to affect or to be affected - what Spinoza calls the 'capacity of doing things or of being acted on' - that makes up the cognitive strength of the mind: a highly sensitive body, highly capable of being affected and of affecting, is a body whose mind is capable of perceiving many things at once, and, by doing so, is also

4 See Treatise on Emendation of the Intellect (TdIE) 85; CWS I, p. 37: 'This is the same as what the ancients said, i.e., that true knowledge proceeds from cause to effect except that so far as I know they never conceived the soul (as we do here) as acting according to certain laws, like a spiritual automaton'. 
capable of rationally understanding the relationships between things (see the Scholium of Proposition 29 of Ethics II).

MATERIALIST EDUCATION AND THE AFFECTIVE SENSIBILITY OF THE BODY

Therefore, the challenge facing a materialist education — an education that, as we have seen, is education in knowledge rather than obedience - is to develop the affective sensibility of the body in order to increase the cognitive sensitivity of the mind, which means to increase its power to act in thought, that is, its power to understand. However, to do this it is necessary to change the body, to transform it even, in the sense that education gives the body another form, another higher nature. The originality of a Spinozist, materialist education lies in exactly this transformation.

In one of the last Scholiums of the Ethics, we read:

In this life, then, we strive especially that the infant's body may change (as much as its nature allows and assists) into another, capable of a great many things and related to a mind very much conscious of itself, of God, and of things. We strive, that is, that whatever is related to its memory or imagination is of hardly any moment in relation to the intellect. ${ }^{5}$

As François Zourabichvili noted in his masterly work on childhood, the subject of the striving in question here is a 'we': conamur, we strive. ${ }^{6}$ This is important because, as Spinoza explains several times, the conatus is a striving to persevere in one's being and not to change into another: it therefore requires the action of another - the 'we' in this case - so that the child's body is changed into another. But who is this 'we'? It is, first and foremost, the collective striving of educators of all kinds, parents, nurses, nannies, childcare workers, paediatricians, teachers, etc. but it can also be the striving of institutions, starting with schools, that contributes to the change in the child's body. It is also the striving of collective practices, care practices, sports education, physical activities, and bodily awareness, all of which contribute to

5 Ethics v, 39 Schol.; CWS I, p. 614.

6 François Zourabichvili, Le Conservatisme paradoxal de Spinoza. Enfance et royauté (Paris: PUF, 2002). 
increasing the abilities of the child's body. This educational striving is essential - we strive to it 'apprime', 'first', says the Scholium, and it is, therefore, a major social striving, and it is (perhaps even more so in Spinoza's time than ours) a matter of life and death. Since death is a threat to childhood, especially early childhood, we must help children to quickly overcome this stage of fragility or physiological weakness; we must help children to build another body, stronger, more resistant, more 'capable'.

At the same time, another important clarification is given in this Scholium: the social body strives to change the body of childhood, quantum ejus natura patitur eique conducit, or 'as much as its nature allows' (patitur: as much as it is acted on), and as much as it assists in it (ei conducit). This expression 'quantum ejus natura patitur eique conducit' is decisive because it adroitly summarizes the terms in which the problem of a materialist education of childhood are played out - namely, the problem of the transformation of the child's sensitive body. This expression also includes a certain ambiguity, as it can be interpreted as a restriction that prevents us from viewing the change effected by education as a real transformation. In this interpretation, the education would change the body as much as it preserves its nature, or to put it another way, it would result in a change 'in' its nature and not 'of' its nature. This latter change is what Spinoza also refers to as a 'death. However, with reference to the Scholium of proposition 39 of Ethics IV, we interpret this change not as a change that simply happens 'to' the body, but a change 'of' its very nature and therefore as a real transformation. Let us read the relevant Scholium:

[...] But here it should be noted that I understand the body to die [mortem obire] when its parts are so disposed that they acquire [obtineant] a different proportion of motion and rest to one another. For I dare not deny that - even though the circulation of the blood is maintained [retenta], as well as the other [signs] on account of which the body is thought to be alive - the human body can nevertheless be changed into another nature entirely different from its own [in aliam naturam a sua prorsus diversam mutari]. For no reason compels me to maintain that the body does not die unless it is changed into a corpse [mutetur in cadaver].

And, indeed, experience seems to urge a different conclusion. Sometimes a man undergoes such changes [tales patiatur 
mutationes] that I should hardly have said he was the same man. I have heard stories, for example, of a Spanish poet who suffered an illness; though he recovered, he was left so oblivious to his past life that he did not believe the tales and tragedies he had written were his own. He could surely have been taken for a grown-up infant [pro infante adulto] if he had also forgotten his native language.

If it seems incredible [incredibile videtur], what shall we say of infants? A man of advanced years believes [credit] their nature to be so different from its own [a sua tam diversam] that he could not be persuaded that he was ever an infant, if he did not make this conjecture concerning himself from (NS: the example of) others. But rather than provide the superstitious with material for raising new questions, I prefer to leave this discussion unfinished. ${ }^{7}$

Beyond the rhetorical precautions given in this Scholium, Spinoza also puts forward a very interesting idea, which despite not being fully founded in reason is stated with sufficient clarity to be identified: namely, that death is not the same as becoming a corpse. Spinozism thus leaves room to think of other forms of death than mere organic death. To illustrate this idea of a non-organic death, Spinoza relies on two examples: firstly, the Spanish poet's amnesia, and secondly the development of the baby, as if the passage from infantia to provecta aetas, from infancy to adulthood, were a form of death.

\section{THE TRANSFORMATION OF THE BODY}

Spinoza certainly advances cautiously on this delicate subject and does not claim that amnesia and adulthood are equivalent to the final death. As so often occurs in Spinoza's discourse, experience is summoned to disturb a habitual conviction: in this example, he means to uproot the identification between death and becoming a corpse. The first experience concerns the amnesia of a certain Spanish poet, who has become forgetful of his own literary creations and is no longer able to recognize what should be most intimate to him or see himself in his works - here amnesia is treated as a certain type of transformation of the body, namely a body defined by its ability to remember. The

$7 \quad$ Ethics IV, 39 Schol.; CWS I, pp. 569-70. 
second experience concerns becoming an adult and is called upon to reinforce this idea of a possible non-cadaveric transformation of the body. Of course, Spinoza does not state in an affirmative way that the baby's body, which has become an adult body, is a body that has met death (mortem obire), but he strongly suggests it, notably by using the expression 'naturam diversam'. In the first half of the Scholium, death is defined as the transformation into a nature totally different from one's own (a sua prorsus diversam); it is then said, at the end of Scholium, that the man of advanced age believes the nature of the baby to be so different from his own (a sua tam diversam) that he needs the mediation of others in order to persuade himself that he was a baby.

It should be pointed out, however, that this is only a 'belief' (credit) and that the adult may be mistaken. The rebuttal could be that the man's nature is not so different from that of the baby and that the baby he was is not necessarily dead. But if we look at the structure of the argumentation of this part of the Scholium, we note that the case of the baby who has become an adult generalizes the case of the poet who has become an amnesiac: Spinoza is telling us that if we consider the rather exceptional case of the Spanish poet incredible (incredibile), then we ought to take the far less exceptional, and therefore much more credible, case of the baby - here 'credit' is the counterpart of 'incredibile', and shows us that the case of the baby has a stronger experiential value than that of the amnesiac poet. Here again, however, we are dealing with a problem of self-recognition: the man of advanced years finds it very difficult to recognize himself in a past which is, in a sense, his own, and because he is also forgetful of this past, he needs others to persuade him that he was once a baby. The man of advanced age is neither in error nor in rational certainty when he 'believes' the nature of babies very different from his own, nor is he in error or certainty when he allows himself to be persuaded by others that he was once a baby. On the one hand, he can see that there is a form of continuity from baby to adult (in others, and therefore in himself), and that is why it is not irrational for him to form the conjecture that he was once a baby but it is only a conjecture (de se conjecturam faceret). On the other hand, he has great difficulty in believing in this continuity of nature, and this difficulty is the indication that he feels that he is no longer the same, that he has experienced an upheaval and that something of 
him has died. It may even be the case - but the text does not make it possible to decide this - that what he feels within himself (the absence of community with the baby) may have more truth than what he convinces himself of via others (the continuity between the baby and himself).

This example shows the ways in which Spinoza provides a definition of death that goes beyond the simple framework of becoming a corpse. He suggests that life cannot be reduced to organic life alone or to the mere preservation of physiological functions. We can call this the life of the body, which is not strictly organic, affective life, but also includes how life is constituted by the connection of images, defined by the remembrance in and by the body, and by the body's ability to affect and be affected. The life of the organic body is certainly necessary for the development of its affective life; moreover, there is no affective life that is not inscribed in a life of organs, tissues, skin, and physiological functions; however, if this life of the affective body is not reducible to the life of the organic body, it is because, according to this Scholium, the organic body can conserve itself while, at the same time, the affective or sensitive body can be transformed. To put it another way: the organic body can live while the affective body can die and become another. This seems to be the case with the example of the baby, which lives on as an organic body but 'dies' when it becomes another affective body. It is important to insist on this becoming other of the affective body because, as long as the organic body endures, the death of the affective body is not a simple disappearance but rather the advent of a new life of the affective body.

If the transformation is indeed what necessarily happens to the body of childhood (infantile amnesia, which concerns the first three or four years, and which occurs around the age of seven or eight, is one of the signs of it), then a materialist education must take note of this transformation, and accompany it as well as possible: it must aim at making the transformation take place in such a way that the infant's body, or more generally speaking the child's body, becomes a body with very great sensory and sensitive aptitudes that are connected to a very intelligent and consciously aware mind. ${ }^{8}$ If one wanted to say

8 See Ethics v, 39 Schol.; CWS I, p. 614: 'And really, he who, like an infant or a child, has a body capable of very few things, and very heavily dependent on external causes, 
things in a provocative way, one could say that materialist education aims at a form of death for the child related to memory and affect and not biology. This form of death induced by the materialist education of the child's body is a way of replacing it with another, stronger body.

However, it should be pointed out here that the aim is to transfer the body of childhood from its first nature to another nature that is suitable for it, one that is really different from the first but not contrary to it. The opposite transformation of the body into a different and contrary nature would be a brutal cadaveric transformation, for example the one produced by suicide. In such a case, as Spinoza points out, the idea of the new nature is not reproduced in the mind, and the transformation amounts to a pure destruction of the one who is transformed. ${ }^{9}$ The whole point of the transformation that accompanies education is to give birth to a new nature which can be affirmed and desired by the one who is educated. This new nature preserves traces of the previous nature as not all memory or all feeling is abolished by it; ${ }^{10}$ it necessarily has properties in common with the previous nature, and there is therefore a degree of continuity, which is why the child can contribute to this transformation ('as much as its nature allows and assists'). But he can do so only under the educational impulse, only through collective striving, since one thing, by itself, strives to persevere in its being, and not to transform itself into another.

The expression 'as much as its nature allows and assists' indicates both the dimension of passivity and the dimension of activity that are specific to the child in changing their body. The nature of the child's body is acted on through such a change, in the sense that effects will be produced in its corporeal nature that are only partially explicable

has a mind which considered solely in itself is conscious of almost nothing of itself, or of God, or of things. On the other hand, he who has a body capable of a great many things, has a mind which considered only in itself is very much conscious of itself, and of God, and of things'.

9 See Ethics IV, 20 Schol.; CWS I, p. 557: 'Someone may kill himself [...] because hidden external causes so dispose his imagination, and so affect his body, that it takes on another nature, contrary to the former [aliam naturam priori contrariam], a nature of which there cannot be an idea in the mind (by IIIP10). But that a man should, from the necessity of his own nature, strive not to exist, or to be changed into another form, is as impossible as that something should come from nothing.

10 See Ethics III, Post. 2; CWS I, p. 493: 'The human body can undergo many changes [multas pati potest mutationes], and nevertheless retain impressions, or traces, of the objects (on this see II Post. 5), and consequently, the same images of things'. 
through it, for although they can indeed be explained in large part by the desires of the educators, by the (more or less conscious) striving of the social body which determines (at least in part) the change in the child's body, Spinoza does not understand the child's body as a passive, receptive object. He also evokes its activity, or rather, to be more rigorous, something like its activity (because 'ei conducit' is not 'ad eum conducit', a syntactic form that would more completely suggest the idea of full participation of the body in this transformation). We see that the child's body does not only undergo this fundamental change, but rather, if the education is successful in terms of not being pure compulsion effecting obedience, then the body in question directly participates in its own transformation. With the expression 'as much as its nature allows and assists' Spinoza suggests that the child stands somehow in-between, that is, between passivity and activity, between a joyful passivity that is not refractory to this useful change, and an inchoate activity that participates in its own transformation, however incompletely. This means that in the 'we' of the conamur, in the collective nature of the educational striving, we can also hear the very striving of the child as they gradually become their own educator.

\section{FROM MORAL EDUCATION TO ETHICAL EDUCATION}

Rather than being called 'education', it seems to me that materialist education should be characterized as 're-education' or 'countereducation. This is because usually education is geared towards obedience, and perhaps it is not even possible to escape this moral education when we are dealing with a relationship between beings who are dominated by the imagination - certainly this is true of children, but it can also be said for most adults. For their own sake, should children not be taught to obey the rules set by parents? ${ }^{11}$ This moral or moralistic education is even useful, since it teaches individuals to conform to the

11 See TTP xVI, 35; CWS II, p. 289:'even though children are bound to obey all the commands of their parents, they are still not slaves. For their parents' commands are primarily concerned with the advantage of the children. We recognize a great difference, then, between a slave, a son, and a subject. We define these as follows: a slave is someone who is bound to obey the commands of a master, which are concerned only with the advantage of the person issuing the command; a son is someone who does what is advantageous for himself, in accordance with a parent's command; and a subject, 
values of the group to which they belong, and teaches them the principle that recognition from the group is offered to those who recognize the group. It thus teaches them a form of autonomy which consists of self-restraint and emotional self-control: in short, ordinary education constitutes the child as a moral subject who is responsible for his or her actions; it produces in him or her an 'ingenium' (a temperament) of self-discipline so that, thanks to this emotional and reflexive interiority, 'it works on its own'. In this respect, we can say of moral education what Michel Foucault says of disciplinary power, the objective of which is not a discontinuous grasp on individuals but a perpetual hold over them, which means that 'one is perpetually in the situation of being watched' - and we could add, in the case of moral education, 'watched by oneself'. Thus, moral education, like disciplinary power, 'looks to the future, to the moment when it will work on its own and when surveillance may no longer be anything more than virtual, when discipline, therefore, will have become a habit. ${ }^{12}$

Spinozist materialist education consists of the work of selftransformation, that is, the transformation of a self that is always first educated for the purposes of obedience: such education is 'countereducation' or 're-education' in the sense of medical re-education, which involves recovering a lost, damaged, or calcified capacity, regaining flexibility, awakening frozen organs, reviving tetanized muscles, undoing (in short) mechanisms which have become hardened in order to produce connections that increase the power of acting. To unbind and to bind again, forming new connection, disturbs what is fixed or frozen and thus produces a liberating disconnection: such is the task of a materialist education that can be deduced from certain passages of the Ethics and which makes it possible to lay the foundations of an education understood as an ethics rather than a moral one.

finally, is someone who does what is advantageous for the collective body - and hence, also for himself - in accordance with the command of the supreme "power"'.

12 Michel Foucault, Psychiatric Power: Lectures at the Collège de France 1973-1974, trans. by Graham Burchell (London: Palgrave Macmillan, 2006), p. 47. In the original, '[le pouvoir disciplinaire] regarde vers l'avenir, vers le moment où ça marchera tout seul et où la surveillance pourra ne plus être que virtuelle, où la discipline, par conséquent, sera devenue habitude' (Michel Foucault, Le Pouvoir psychiatrique. Cours au Collège de France. 1973-1974 (Paris: Gallimard Seuil, 2003), p. 49). 
The first text to be considered from the Ethics is one of the few where education is explicitly mentioned.

[...] it is no wonder Sadness follows absolutely all those acts which from custom are called wrong, and Joy, those which are called right [omnes omnino actus, qui ex consuetudine pravi vocantur, sequatur tristitia, et illos, qui recti dicuntur, lætitia]. For from what has been said above we easily understand that this depends chiefly on education [nam hoc ab educatione potissimum pendere]. Parents - by blaming the former acts, and often scolding their children on account of them, and on the other hand, by recommending and praising the latter acts - have brought it about that emotions of Sadness were joined to the one kind of act, and those of Joy to the other [parentes nimirum, illos exprobanbo, liberosque propter eosdem sæpe objurgando, hos contra suadendo, et laudando, effecerunt, ut tristitiæ commotiones illis, lætitiæ vero his jungerentur].

Experience itself confirms this. For not everyone has the same custom and Religion. On the contrary, what among some is holy, among others is unholy; and what among some is honourable, among others is dishonourable. Hence, according as each one has been educated, so the either repents of a deed or exults at being esteemed for it. ${ }^{13}$

What is ordinary education? It is about valuing some actions and devaluing others. For educators, first and foremost parents, it is a question of associating affects with certain acts (performed by children) so that these acts are perceived - or better said, felt - as positive or negative. Education, in terms of cognitive development and the direction of conduct, is above all an undertaking that produces cognitive-affective connections in the child in order to solicit or prevent certain behaviours: it consists in combining (jungere) the representation of certain acts with emotions (commotions) of joy or sadness.

How is this junction between representations and emotions achieved? First, through an operation of nomination (vocantur, dicuntur) that depends on customs (ex consuetudine): based on traditional ways of speaking about the group to which they belong, parents interpret certain acts and use terms charged with positive or negative affects ('wrong', 'right', 'good/bad', 'kind/bad'). At the same

13 Ethics III, DA xxvir Exp.; CWS, I, p. 537. 
time, parents repeatedly formulate reproaches or encouragement by blaming, reproving, and reprimanding (exprobrando, objurgando), or congratulating, exhorting, and praising (suadendo, laudando). In short, it is a question of the parent attaching (sequatur) an emotion to the representation of the act the child has committed, which in turn either increases or diminishes the child's power to act. On the basis of this production of an association between representation and emotion more complex affects are then formed, which can be sorted into the two types of love or hatred (love being a 'joy accompanied by the idea of an external cause' and hate a 'sadness accompanied by the idea of an external cause'). ${ }^{14}$

The educational operation therefore shows that the very act performed by the child, in itself, can be perfectly 'innocent': it only becomes a moral act through the habit of appointment, and of valuation or devaluation, which is performed by the parents.

Through this activity of cognitive-emotional conjunction, ordinary education - which we would gladly call 'moral education' consists in producing in the child aspirations towards or repudiations of certain acts, and not only concerning behaviours but also thoughts or feelings. But whether or not these acts have an external expression, or remain within the interiority of the child, the essential thing is that they do not refer to 'external causes' but to 'internal causes' - that is, to the 'interiority' of the child. This psychological interiority is even constituted by the moralistic education of the child, which produces in him what we can call 'self-love' or 'self-loathing', and which Spinoza more readily calls 'self-esteem' or 'repentance', or 'love of esteem' and 'shame', these two affects being the socialized forms of satisfaction and repentance. ${ }^{15}$ All education contributes to the activation of this law in the child:

If someone has done something which he imagines affects others with Joy, he will be affected with Joy accompanied by the idea of himself as cause, or he will regard himself with Joy. If, on the other hand, he has done something which he imagines affects others with Sadness, he will regard himself with Sadness. ${ }^{16}$

14 See Ethics III, DA vi and viI; CWS I, p. 533.

15 See Ethics III, 30 Schol.; CWS I, pp. 511-12, and IV, 52 Schol.; CWS I, p. 523.

16 Ethics III, 30; CWS I, p. 510. 
Education therefore produces in the child a self-awareness which is above all a moral awareness: by producing in the child affects of joy and sadness 'which are accompanied by the idea of an internal thing as cause, ${ }^{17}$ ordinary education makes for the child a cause, a moral cause of affects that reward or sanction which is produced through the judgment of others and the good or evil that has been done. The moral educator's challenge is to produce cognitive-emotional sequences in order for the child to form judgements about themself, to rejoice or to feel sad about themself: the child learns to make value judgments not first of all about things or other people but about themself and their own actions - whether of the body, of language, thought, or of desire. In order to behave well, they learn a kind of reflexivity which is first of all an emotional reflexivity: they learn to glorify themself or to repent. They are trained to train themselves, since there is no better government of the other than a government of the affects by which the other governs themselves

Such an education gives rise to an indefinite multiplicity of concrete educational practices, customary forms of moral education, which are often based on religion. However, I would like to distinguish an education that the Theological-Political Treatise characterizes as 'good'18 and that from the Ethics we could qualify, precisely, as 'ethical' from these other forms of moral, social, and religious education. Its most significant quality is that it does not submit to a power as soon as it becomes tyrannical. ${ }^{19}$ Therefore, good education is characterized by a political virtue, namely resistance to abuse of power; and this resistance itself is characterized by two remarkable properties: its form (speaking out) and its radicality (resistance to the peril of one's life). According to Chapter Xx of the Theological-Political Treatise, these two characteristics have emotional prerequisites: in a negative way, they imply not being carried away by certain affects, those that lead to submission (greed or sycophancy), but also and especially the fear of death; and, in a positive way, possessing and cultivating a 'moral force' and a love of freedom, above all the 'freedom to speak'.

17 See Ethics III, DA xxiv Exp.; CWS I, p. 536.

18 ТTP viI [90]; CWS II, p. 206, and xx [28]; CWS II, p. 349: 'good education [bona educatio]'

19 See TTP xx (the end). 
However, the production of such affects, which run counter to the affects of subjection, requires the defeat of ordinary loves and hatreds and the development of new sequences of affections - those which proposition 10 of Ethics $\mathrm{v}$ tells us are made 'according to an order for the intellect'. Good education is above all an education in reason: an education in the affected reason, which is at the same time an education in rational affectivity.

Who is such an education for? For children, undoubtedly, since a good education doubles ordinary education and develops in the child (alongside moral affectivity and self-discipline) a desire for rationality and freedom: if such an education does not produce rationality in them, it at least can cultivate the beginnings of adequate thought, which is above all thought aimed at continuous reform. This makes possible, if only at a later time, a re-education of passionate selfsatisfaction. This good, rational education is also aimed at adults if they are eager for a new, firmer, and more serene existence. For Spinoza places this task of re-education is very high on the agenda. ${ }^{20}$

While Spinoza did not write the 'science of education' mentioned in the prologue to the Treatise on the Emendation of the Intellect, he at least showed in the Ethics a real concern for education, so much so that one might wonder whether this treatise on the science of education would not have ended up resembling the Ethics or have been somehow a derivative of it. And in more general terms, we should understand Spinoza's ethics as a practical philosophy that consists of a materialist education - of children and of oneself - aimed at transforming the affective sensibility of body and mind.

20 See Ethics IV, App. Ix; CSW I, 589: 'because, among singular things, we know nothing more excellent than a man who is guided by reason, we can show best how much our skill and understanding are worth by educating men so that at last they live according to the command of their own reason'. 
Pascal Sévérac, 'A Materialist Education: Thinking with Spinoza', in Materialism and Politics, ed. by Bernardo Bianchi, Emilie Filion-Donato, Marlon Miguel, and Ayşe Yuva, Cultural Inquiry, 20 (Berlin: ICI Berlin Press, 2021), pp. 181-96 <https://doi.org/10.37050/ci-20_10>

\section{REFERENCES}

Foucault, Michel, Le pouvoir psychiatrique. Cours au Collège de France. 1973-1974 (Paris: Gallimard Seuil, 2003)

- Psychiatric Power: Lectures at the Collège de France 1973-1974, trans. by Graham Burchell (London: Palgrave Macmillan, 2006)

Ravaisson, Félix, La Philosophie en France au XIx ${ }^{e}$ siècle (1867) (Paris: Vrin Reprise, 1983)

Spinoza, Benedictus de, The Collected Works of Spinoza, ed. and trans. by Edwin Curley, 2 vols

(Princeton, NJ: Princeton University Press, 1985-2016)

Zourabichvili, François, Le Conservatisme paradoxal de Spinoza. Enfance et royauté (Paris: PUF, 2002) <https://doi.org/10.3917/puf.zoura.2002.01> 